\title{
The Impact of Drug Abuse in the Social Perspective on the Young Generation in South Sulawesi
}

\author{
( lecturer of Stikes Nani Hasanuddin Makassar, in Makassar ,South Sulawesi)
}

\begin{abstract}
This type of qualitative research through fenomenology approach, Adolescence is a time of transition, where time is crucial in the determination of a person's life overall. This period is a period prone by negative influences, such as drugs. Drug relationship with teenagers nowadays is very tight. This means that many cases involving drug abuse teens. The biggest factor that becomes the cause is psychological instability of the teenager in the face of the problems of life in family, school, and community, in addition to other factors such as environmental influences or powerful drug syndicates. Drug abuse provides a very broad impact. Not only for the teenagers themselves, but also for people in the surrounding area include the social impact to psychological. Various methods of recovery for drug abusers into alternative areas such as Integrated Counselling Methods. However, once caught the drug then it will be hard to break free from it. Therefore, how important countermeasures that include preventive (precautionary), cure (eradication), and construction (socialization-promotif). Need the participation and awareness of all parties, parents and family until adolescence itself.
\end{abstract}

Keywords: Policy, Teenagers, Generation, Impact, Family.

\section{INTRODUCTION}

The history of the rise of the circulation and illicit drug abuse can be traced back hundreds of years ago in which psychoactive drugs used for the treatment of religious (religious) and as entertainment (recreational purpose). And at the end of the 19th century, with the growing science of chemistry and Pharmacology society began to synthesise a range of substances that are very strong and very addictive that can lead to addiction, such as cocaine and heroin.

The problem of drug abuse in Indonesia is a serious problem that must be resolved the way the solution immediately. Many cases that show how the result of the above problem has caused many losses, either material or non material. Many events, such as a divorce or other difficulties even deaths caused by a dependency against narcotics and illicit drugs.

The impact of physical, psychic and social closely linked. Physical dependence will result in tremendous pain (sakaw) If you happen to break up a drug (not taking medication at the time) and a psychological boost in the form of a very strong desire to consume (gaulnya sugest). Physical and psychological symptoms also are associated with symptoms such as social impetus for lying to parents, stealing, petulant and manipulative.

Drug relationship with younger generation nowadays very closely. This means that very many cases of addiction and drug trafficking which engage the younger generation. Even drugs have entered the school and campus. Still includes drugs, namely alcoholic beverages, which is very frowned upon the youth school, even schools that are far from big cities. This small town found sellers of alcohol in small packs-packs sold in a street near the school with the price of a hundred to two hundred dollars a pack. Clearly the kind of low-quality drink so students faster jazzed. Due to the use of drugs, then the crime rate of the students in major cities look very inflated. Inter-school fights occur, seizure school bus with the intention of asking for money and forced the passengers. Sometimes they are robbing with violence and sharp objects.

The issue of the use of illicit drugs to alcohol among teenagers have since long been a big problem, and even lately entered the category of "concentrated" problems or diseases of society. Various efforts have been undertaken by different parties with different approaches and ways of eradicating the disease as well as a aims of impact — evokes a negative impact. The most alarming circumstance is swept the State was precisely among adolescents as young shoots the successor Nations. Many people who are worrying about the future of the nation in adolescents more entangled behavior of drug abuse.

Remember the teenager as a successor to the ideals of the nation and religion, it needs to be a serious coaching from various parties both parents, community leaders, religious figures, teachers as well as the Government itself so that the problem faced by teenagers can be resolved and they survived from his teenage years. And as understandably, adolescence is in the process of human development with certain characteristics. This time have the most strategic in the whole life of the person. The future of a person is determined by the success or failure in entering adolescence. Usage of illicit drugs and alcohol by adolescents is one source of failure of adolescence. Based on the foregoing, the author then interested in elevating the issue of adolescence and drug abuse in this paper.

In demographics, drug users "in General is a private, self-employed workers and workers who are over 30 years old with education level most SLTA. Head of BNN, Komjen. Pol. Goris Mere says, which is quite alarming was the large amount of drug users from the student/learner, 
which amounted to 3.8 million in 2010. Based on the above facts, trends are expected to tend to experience increased. The BNN estimated prevalence (number of Genesis) drug abuse in Indonesia will reach approx. 5.1 million people in 2015. But if the trend of nearly consistent, estimates the year 2015 could be increased up to double to about 10 million people. "Judging from its graph, drug cases tend to increase every year in the past five years," BNN outlines the Data, in 2006 there were many u.s. national 17.355 u.s. drug case consisting of narcotics cases and 9.4225 .658 psychotropic substances. While in 2007, was recorded there as much as 22.630 the case i.e. 11.380 narcotics cases and as much as psychotropic substances 9.289 case. Furthermore, in 2008 there were 29.364 summarizes many of the U.S. u.s. the BNN case drugs where about 10.008 is a case of narcotics and the rest or around 9.783 case psychotropic substances. For the year 2009, increasing again became 30.878 cases comprising cases of narcotics and psychotropic substances to 11.1358 .779 . The last in the year 2010 there are many cases where the U.S. 26.614 all-around 17.834 is a case of narcotics while the rest or around 1.181 is the case of psychotropic substances. In total based on its kind, in the case of narcotics throughout the year there are many us us five 59.779 cases and for psychotropic substances there are about 34.690 cases. The situation of production and circulation of drugs is so great, the effect on the condition of the misuse of sacred items. This is according to him can be seen from the cases of abuse and illicit drugs in Indonesia who each year are likely to continue to experience increased quite significantly. Even according to national data were released 5 over the centuries, the BNN that year, there were many u.s. u.s. 356 cases of drug production in the country. While for the Hustler who successfully caught the U.S. there are many us 107.069 people. 2. Asean In demographic, "drug users generally are private, self-employed workers and workers who are over 30 years old with education level most SLTA. Head of BNN, Komjen Pol Goris Mere says, which is quite alarming was the large amount of drug users from the student/learner, which amounted to 3.8 million in 2010. Based on the above facts, trends are expected to tend to experience increased. The BNN estimated prevalence (number of Genesis) drug abuse in Indonesia will reach approx. 5.1 million people in 2015. But if the trend of nearly consistent, estimates the year 2015 could be increased up to double to about 10 million people. "Judging from its graph, drug cases tend to increase every year in the past five years," BNN's Data, outlines, in 2006 there were many u.s. national 17.355 u.s. drug case consisting of narcotics cases and 9.422 5.658 psychotropic substances. While in 2007, was recorded there as much as 22.630 the case i.e. 11.380 narcotics cases and as much as psychotropic substances 9.289 case. Furthermore, in 2008 there were 29.364 summarizes many of the U.S. u.s. the BNN case drugs where about 10.008 is a case of narcotics and the rest or around 9.783 case psychotropic substances. For the year 2009, increasing again became 30.878 cases comprising cases of narcotics and psychotropic substances to 11.1358 .779 . The last in the year 2010 there are many cases where the U.S. 26.614 all- around 17.834 is a case of narcotics while the rest or around 1.181 is the case of psychotropic substances. In total based on its kind, in the case of narcotics throughout the year there are many us us five 59.779 cases and for psychotropic substances there are about 34.690 cases.

\section{A. Formulation of the Problem}

How the Impact of Drug Abuse in the Social Perspective on the Young Generation in South Sulawesi.

\section{REVIEW OF THE LITERATURE}

\section{A.Drugs}

The drug is derived from the word Greece "narkoun" which means to make paralyzed or numb. The history of long life. Around 5000-6000 BC, the Mesopotamian people have been cultivating poppy crops which helps reduce pain and provide comfortable effect (joy plant). These substances are in the language of Greece referred to Opium or we know as opium. [22] in $2737 \mathrm{BC}$, the Chinese emperor named Shen Nung wrote the scripts pharmacy called "Pen Tsao" or "Herb" (Great Herbal). One herb that is called the "liberator of Sin" or "giver's delight" (the giver of pleasure) devoted to pleasure, the drug agency's weak, malaria, rheumatism, and analgesics. Current drugs has spread to the rest of the world is consumed by various circles, especially teenagers, especially in the United States and Africa. Currently the worldwide drug epidemic has already poisoned the young generation. It is assumed in the year 2001 alone, in Indonesia there are already four million drug users, where Chairman Grenade (Anti Narcotic Movement) Henry Yosodiningrat that turnover of drugs in Indonesia currently totaling 24 trillion rupiah per month. This is a fantastic figure. The specified number, if each day a user do drugs for Rp. 200,000,-then one day results turnover reached four million x Rp. 200,000,-= Rp. 800 billion.

A drug is a drug, substance, or material and the material is not classified u.s. foods, if drunk, sucked up, and inhaled, ingested, or injected, influential especially on the work of the brain (central nervous arrangement), and often leads to dependence. As a result, the brain works changed (increased or decreased); Similarly, other organs of the body's vital functions (heart, circulatory, respiratory, and others). Drugs classified u.s. psychoactive substances. The intended psychoactive substances are substances that primarily affect the brain causing changes in behavior, feeling, mind, perception, and consciousness. Drugs (Narcotics and drugs or hazardous materials) is a term of law enforcement and the community. Drugs (Narcotics, psychotropic drugs, Other addictive substances) is a term in medicine or health care, where the emphasis is the influence of dependency. Therefore, in addition to the narcotic drugs and psychotropic substances, which include Drugs are drugs or substances are not regulated in legislation but cause 
ISSN No: - $2456-2165$

dependence and often misused. For example alcohol, nicotine, an inhalant, or solven.

However, the length of the right drug is narcotic, psychotropic drugs, and other addictive ingredient. Used the term drug because it has become the common language in the community. However, the space in scope covering Drugs because of other addictive substances such as alcohol, nicotine and often become the entrance of another dangerous drug usage. follows:

Hazards arising from drug abuse in the General u.s.

\section{Physical aspects}

kidney failure

$>$ fatty deposits in the liver, the diminution of the liver, liver cancer

$>$ pneumonia, inflammation of the membranes of the lungs, pulmonary tuberculosis

> susceptible to various diseases hepatitis B, Hepatitis C, and HIV/AIDS

$>$ Fetal Defects

$>$ Impotence

$>$ menstrual disorders

$>$ the pale result less blood (anemia)

$>$ memory/forgetting disease of senile

$>$ brain damage

$>$ the stomach Bleeding

$>$ the pancreas Inflammation

$>$ nerve Inflammation

$>$ Easy bruising

$>$ Impaired heart function

$>$ causing death

\section{Psychological aspects}

$>$ uncontrolled Emotions

$>$ excessive Suspicion to the level Waham (not in line between thought and reality)

$>$ always lie

Do not feel safe

$>$ not being able to take a reasonable decision

$>$ have no responsibility

$>$ excessive Anxiety and depression

$>$ outstanding Terrified

$>$ Lost memories (crazy)

\section{Social aspects}

$>$ Relationships with family, friends and teachers, as well as the environment are compromised

$>$ Disturbing public order

$>$ always avoid contact with other people

$>$ Feel excluded or withdrew from the positive environment

$>$ is not concerned with the existing norms and values

$>$ have sex freely

is not concerned with the existing norms and values perform acts of violence, whether physical, psychological or sexual

stealing.

Drug abuse generally occur in adolescents who live in urban areas. They will usually have properties not quick, relatively Cosmopolitan married having to traverse a period of study up to university level, even to get a job is considered feasible. In the days that they live in Transition; between childhood and maturity, both physical, mental, or Sociocultural. He lived between freedom and dependence to parents; they exist in the establishment of its own as well as his attitude, his grades good religious attitudes, as well as its social and cultural attitudes. Teenagers are seeking the identity of his attitude to the environment and each other. In conditions that are often duplicitous all-round teen slipping into the path of delinquency, juvenile delinquency is called. At that time many teens who do mischief, violation of the law, even a criminal offence. His motivation is to get the attention of the "social status", and in recognition of the existence of himself.

In other words, juvenile delinquency is a form of a statement of the existence of the self in the middle of the neighborhood and its people, not mere delinquency. One of the departures this behavior is sexual behavior. While one form of violation of the law is to drink liquor, marijuana to illegal drugs and other addictive substances.

\section{RESEARCH METHODS}

This type of qualitative research through fenomenology approach.

\section{DISCUSSION}

Behavior deviation in the form of drug abuse is primarily a reflection of psychological problems experienced by teenagers. Problems were intertwined with other problems especially in the family. The family is the beginning of the source of the problem and will have an impact of that issue. The problem was related to psychological issues, economic, moral, culture, values, and physically. All of that can lead to psychological problems that may arise in the family such as: the atmosphere of tension in the family, the future is grim, declining resilience in families, and aggressive attitude of hostility, ineffective communication, less confident, indifference, and so on. The overall atmosphere of the family will be the more dismal and further from a happy family life. The most severe consequences of course for itself as a successor of the life. And imagine how the future is concerned and the nation as a whole in the present moment is in the case.

The widespread drug abuse in Indonesia especially among the younger generation is also mainly due to cultural factors underpinned by global. Global culture dominated by Western culture (United States) to develop its influence through the TV screen, VCD, and films. The main characteristic of these cultures very easily emulated and 
ISSN No: - $2456-2165$

adopted by the younger generation because according to the needs and tastes of the young. The penetration of Western culture to Indonesia easily observed through the Association of young children (MCA). Characteristics of the intercourse of MCA was "free", consumerist, and hungry for all sorts of fashions that come from A,. If the clothes the performers on TV open-openings, and even consuming drugs, then MCA ever emulate.

The growing number of addicts among adolescents is determined by two factors, i.e. factors inside and outside yourself. The deciding factor in themselves are: (1) interest (2) curiosity (curiosity) (Hurlock, 1978), (3) the weak sense of Divinity (Abu Hanifah, 1989), and (4) unstable or invalid emotions (Duke and Norwicki, 1979). While the factors that come from outside yourself is: (1) family psycho-social disorders, (2) weak law against traffickers and drug users, (3) weak school system including guidance and counselling (BK), as well as the most important (4) weak religious education students schools (Sofyan s. Willis, 2001).

From different sides, there are three factors the causes of drug abuse. The third factor is drugs, individuals, and the environment. Drug factor talked about pharmacological substances, namely the type, dosage, how to wear, its influence on the body, as well as the availability and control its release. From an individual, drug abuse must be understood from a complex behavioral issues, which is also influenced by environmental factors. The environment talked about family, peer group, school life and the wider community, the mass media, and local law enforcement. Of the three, the most important factor is the individual. Someone has to take responsibility for his behavior and should not count on other people or circumstances.

According to developmental psychologists (Papalia et al., 1998; Santrock, 1999; 2001; Thornburg, 1982), there are several reasons why teenagers do drug abuse, among other:

\section{A. The immature Personality (Immature Personality)}

During this time, the teen entered a search in the formation of the identity of the self (self identity). In this case, the personality of the adolescent has not yet reached maturity (immaturity). According to developmental psychologists, private mature characterized by the nature of doubt (indecisiveness) in taking a decision), lacking confidence or low self esteem, less able to control their emotions and behavior. This state allows teens to easily influenced things negatively or positively by the external environment. When he obtained a positive influence, this will benefit the development of the personality, for example, develop scientific activities in the Scientific Paper Competition. Instead, he will be able to obtain a negative influence, so that teenagers would be easy fall on the negative actions, such as get involved in drug abuse.

\section{B. Lineage (genetic)}

Research conducted in the various Western countries, like the United States, United Kingdom, Germany (in Papalia et al., 1998) found that hereditary factors influence against bringing the properties of physical or psychic, such as characteristics, habits, or the personality of the person. The parents are alcoholics, drugs (marijuana, opium, cocaine, amphetamine) tend to give birth to children who are growing and expanding as the addict later in life than children born of parents who are not drug addicts. Although not mentioned how much percentage chances of occurrence of dependency, but from this research can be said that hereditary factors (genetic, heredity) have contributed to the incidence of drug addiction on a person.

\section{The living conditions of families are unstable (Stormy)}

The family is the first environment for the establishment and development of a child's personality. A good family life is characterized by harmonious relationships, harmony, and balanced among family members. In this case, there is communication (two-way interaction) between married couples and parents of the child. Thus, it will form a mature personality for the child. The child can adapt to the social environment, without being affected by bad relations, including drug abuse. In contrast, an unstable family life, for example, often arising out of contention, conflict to divorce spouses (broken-home), tend to make an individual (teens) are not welcome to stay at home. As a result, teens looking for a way to escape, such as using drugs even then raises the dependence upon him.

\section{Strong syndicate of Drug Circulation Network}

There is an attraction between the parties think of the importance to develop the personality of the adolescent (younger generation) became the successor of the nation and business interests of the younger generation of destructive momentary nation. For the second, the important thing is to gain that much. Therefore, strong syndicate network drugs will enter circulation in terms-in terms of the life of the community with the goal of children, teenagers, or young men. When the syndicate was not able to be solved by law enforcement authorities, the syndicate may be aggravating circumstances so that many teenagers easily become targets and to finally experience of drug addiction (Media Indonesia, 2002). If the goods are haram named drugs not available or difficult to find, then of course, there will be no people abuse it. However, the fact that the various types of drugs are thus easily people get it.

Another factor that is often overlooked but indeed affect drug abuse is smoking. In fact, the relationship is directly between smoking and drugs did not exist, so that smoking remains permitted to produced and circulated. With notes, in any packaging, manufacturer of smoking include warning of the dangers that can be caused by smoking. 
Nevertheless, smoking can be said to be a gateway drug. Why is this so? With the smoke of mind or brain someone will become empty and pushed for daydreaming. Generally the same effect also produced by drugs with the potential of a stronger. Smoking is also addictive. Once the smoke of its users will continue to smoke. Therefore, it is not surprising that smokers are generally happy to try something that yields such pleasures. They are usually more easily tempted if anyone offers a drug, alcohol, psychotropic drugs, or other addictive substances.

The drug is a scary Specter for the younger generation. Seduction and temptation to use drugs so powerful. When in fact the negative effects of drug abuse is so great. Bad impact caused include physical disorders (health), mental (psychic) as well as disruptions in the social life of its users. Regarding the negative impact on health and also a psychic had existed in the previous article. And on this occasion I want to inform about the negative effects of drug abuse on the lives of social users. And the negative effects of drug abuse on the lives of the social is as follows:

\section{E. Be ostracized by their environment}

The drug users are generally not going to be liked by their surroundings. Because drug users tend to be perceived as people who have bad behavior. So drug users will be ostracized by the neighbourhoods where he lived.

\section{F. Hassle other people and become a burden on the family}

The subsequent impact of drug abuse is a hassle surrounding people. And even family will join the bear the brunt of his deeds. The family will join the bear the shame and scorn from people who didn't like the things that smelled of drugs.

\section{G. The future bleak}

This scourge of the moment. How the drug can destroy the future users. Drugs can lead to lazy people educated, lazy work and prefer doing the smelling pleasure without thinking of the future. As a result, his future became murky and unclear. It is clear that drug abuse was a detriment. Not only is self-defeating but also harm other people, was no exception.

So, stay away from drugs because it is better to prevent than to treat. Better do not approach than later regret later.

A variety of efforts tackling growing drug addict, has done. People become addicted to the drug through a long process, not happened overnight. It usually starts with a try, and then increase the use time, for example, sometimes a party or other event. When its use quite often, comes the stage of abuse and eventually addiction. Therefore, the healing process also takes a long time, cannot occur instantaneously as expected by society or an addict.
Recovery is the process of healing from physical damage, psychological, and social consequences of drug addiction. Recovery is the process of individuals, no two people recovered with equal speed.

Attempts to restore an addict not just physically health recovery of the victim, but rather the recovery of intact and carried out by teams that are solid and professional starting from the planning stages until evaluation. Usually a variety of therapy is done on the rehabilitation therapy includes, among others, medical, physiological and mental and psychiatric therapy, inner and spiritual deepening therapy, therapy, recreational therapy and interests of community and social work therapy, and finally and Polytechnic. In addition, the root of the problem that triggered them eventually consume drugs should also be resolved completely, attempts to restore (recovery) of a drug addict is medically and psychologically in our country are mostly based on ways the United States is done. In the country since the 1960s there has been some rehabilitation centres. The United States leading rehabilitation in 1967 only has 16 beds, but 9 years later the parlors have has 112 beds. It means an increase in addicts have significantly each year.

The current model is very oriented towards medical and psychological. That is, during the initial phase the addict taken to hospital Drug Dependent (RSKO). About that Mann (1979) a medical doctor will doubt the efficacy of RSKO on recovery of the total (total recovery) patients with detoxification, nutrition/vitamin therapy, and giving the drug control the emotions of the patient. Therefore, Mann praised the approach of The leading rehabilitation SHCR as parlors in the United States, because there the patient not only cured through treatment approach, but also psychological rehabilitation approach, social, intellectual, spiritual, and physical.

\section{CONCLUSION}

The use of illicit drugs to alcohol among teenagers have since long been a big problem, and even lately entered the category of "concentrated" problems or diseases of society. Various efforts have been undertaken by different parties with different approaches and ways of eradicating the disease as well as a aims of impact evokes a negative impact. The most alarming circumstance is swept the State was precisely among adolescents as young shoots the successor Nations. Many people who are worrying about the future of the nation in adolescents more entangled behavior of drug abuse.

\section{BIBLIOGRAPHY}

[1]. Adam. 2007. Jurnal Ilmu Dakwah: Muballigh dan Pembinaan Remaja. Palu:STAIN Datokarama Palu.

[2]. Ajisuksmo, Clara R.P. dkk.. 2001. Narkoba: Petujuk Praktis Bagi Keluarga Mencegah Penyalahgunaan Narkoba. Yogyakarta: Media Pressindo. 
[3]. Ali, Muhammad, Mohammad Ashori. 2004. Psikologi Remaja: Perkembangan Peserta Didik. Jakarta: Bumi Aksara.

[4]. Amriel, Reza Indragiri, M Crim. 2007. Psikologi Kaum Muda Pengguna Narkoba. Jakarta: Salemba Humanita.

[5]. Depsos RI, Brosur Direktorat Pelayanan dan Rehabilitasi Sosial Korban NAPZA.

[6]. Djauzi, Samsuridjal.2009. Raih Kembali Kesehatan. Jakarta: Buku Kompas.

[7]. Gunarsa, Singgih D.. 2004. Dari Anak Sampai Usia Lanjut. Jakarta: BPK Gunung Mulia.

[8]. Gunawan, Weka. 2006. Keren Tanpa Narkoba. Jakarta: Grasindo.

[9]. Kartono, Kartini. 2008. Kenakalan Remaja. Jakarta: Rajawali Grafindo Persada.

[10]. Libertus Jehani, dkk.. 2006. Mencegah Terjerumus Narkoba, Tangerang: Visimedia.

[11]. Martono, Lydia Harlina. 2006. 16 Modul Latihan Pemulihan Pecandu Narkoba Berbasis Masyarakat. Jakarta: Balai Pustaka. 2008.

[12]. Belajar Hidup Bertanggung Jawab Menangkal Narkoba. Jakarta: Balai Pustaka.2008. Peran Orang Tua dalam Mencegah dan Menanggulangi Penyalahgunaan Narkoba. Jakarta: Balai Pustaka.

[13]. Partodiharjo, Subagyo. 2007. Kenali Narkoba dan Musuhi Penyalahgunaannya. Jakarta:

[14]. Erlangga. Surbakti. 2009. Kenalilah Anak Remaja Anda. Jakarta: PT Alex Media Komputindo.

[15]. Surya, Mohammad. 2004. Bina Keluarga. Semarang: Aneka Ilmu.

[16]. Tim Visimedia. 2006. Rehabilitasi Bagi Korban Narkoba. Tangerang: Visimedia.

[17]. Willis, Sofyan S.. 2008. Remaja dan Masalahnya. Bandung: Alfabeta.

[18]. Zahra, Ruswiyani P.. 2005. Lingkungan Keluarga dan Peluang Munculnya Masalah Remaja( Dalam Jurnal Provitae No.2). Jakarta: Yayasan Obor Indonesia.

[19]. Effendi, Luqman, 2008. Modul Dasar-Dasar Sosiologi\&Sosiologi KesehatanI. Jakarta: Pskm Fkk Umj.

[20]. Kartono, Kartini, 1992. Patologi II Kenakalan Remaja. Jakarta: Rajawali.

[21]. Mangku, Made Pastika, Mudji Waluyo, Arief Sumarwoto, dan Ulani Yunus, 2007. pecegahan Narkoba Sejak Usia Dini. Jakarta: Badan Narkotika Nasional Republik Indonesia.

[22]. Shadily, Hassan, 1993. Sosiologi Untuk Masyarakat Indonesia. Jakarta: Pt Rineka Cipta.

[23]. Soekanto, Suryono, 2006. Sosiologi Suatu Pengantar. Jakarta: PT Raja Grafindo Persuda Sofyan, Ahmadi, 2007. Narkoba Mengincar Anak Anda Panduan bagi Orang tua, Guru, dan Badan Narkotika dalam Penanggulangan Bahaya Narkoba di Kalangan Remaja. Jakarta: Prestasi Pustaka Publisher.

[24]. Sudarman, Momon, 2008. Sosiologi Untuk Kesehatan. Jakarta: Salemba Medika.

[25]. Syani, Abdul, 1995. Sosiologi dan Perubahan Masyarakat. 